\title{
PENGEMBANGAN KEWIRAUSAHAAN DENGAN MENCIPTAKAN WIRAUSAHA BARU DAN MANDIRI
}

\section{Enny Widayati, Haswan Yunaz, Tagor Rambe, B.Wishman Siregar, Achmad Fauzi, Romli} Institut Bisnis \& Informatika Kosgoro 1957

A R T I C L E I N F O

Keywords: Ideas, Observing, Forms of Business

Kata Kunci: Ide, Mengamati, Bentuk Bisnis
Abstract : Ideas for starting a business or business begins with observing the environment. Usually new ideas emerge as a result of the process of one's interaction with the environment. Therefore the choice of environment and form of business must be observed carefully. Here an entrepreneur must be observant in assessing and handling various problems and opportunities that arise in the environment. For example, there are two prospective entrepreneurs coming to a community somewhere. These two people found the same fact that everyone in the community did not wear shoes or sandals. After studying and identifying the cause, prospective entrepreneur A concludes there is no point in starting a shoe business here because A believes that the behavior of people who are not shoes or sandals are ingrained and cannot be changed.

Abstrak: Ide-ide untuk memulai sebuah usaha atau bisnis diawali dengan mengamati lingkungan. Biasanya ide baru muncul sebagai hasil dari proses interaksi seseorang dengan lingkungan. Oleh karena itu pilihan akan lingkungan dan bentuk bisnis harus diamati dengan seksama. Di sini seorang wirausahawan harus jeli dalam menilai dan menangani berbagai permasalahan dan peluang yang muncul di lingkungan tersebut. Sebagi contoh, ada dua orang calon wirausahawan datang di sebuah masyarakat di suatu tempat. Dua orang ini menemukan kenyataan yang sama bahwa semua orang dalam masyarakat tersebut ternyata tidak memakai sepatu atau sandal. Setelah mempelajari dan mengidentifikasi penyebabnya, calon wirausahawan A menyimpulkan tidak ada gunanya memulai bisnis sepatu di sini karena A berkeyakinan perilaku masyarakat yang tidak bersepatu atau sandal ini sudah mendarah daging dan tidak bisa diubah.

\author{
Corresponding author: \\ Achmad Fauzi \\ Achmad_fauzioke@yahoo.com
}




\section{Latar Belakang}

\section{PENDAHULUAN}

Direktorat pengabdian pada masyarakat DRPM Dikti mempunyai strategi mengejar ketertinggalan Indonesia dengan membuat Program Pengembangan Kewirausahaan (PPK) ini dapat memberikan angina segar bagi kampus IBI Kosgor 1967. Target kegiatan PPK ini adalah :

1. Mengembangangkan jiwa wirausaha bagi mahasiswa dengan cara memberikan bekal melalui :

a. Pemberian pengetahuan teori konseptual manajerial tentang wirausaha dengan mengadadkan pelatihan

b. Melatih mahasiswa tentang menciptakan peluang usaha.

c. Menciptakan wirausaha baru dan mandiri.

2. Meningkatkan keterampilan manajemen bina usaha

3. Menciptakan metode pelatihan kewirausahaan dan jenis usaha yang cocok untuk mahasiswa

4. Magang di perusahaan industri sesuai dengan minat tenant.

Kegiatan ini dimulaidengan sosialisasi adanya kegiatan PPK, dengan sasaran agar mahasiswa tertarik untuk ikutseleksi(Recruitmenttenant)untuk mendapatkan mahasiswa yang betul-betul mempunyai minat wirausaha.

Jenis usaha yang akan dihasilkan dari kegiatan ini 5 jenis usaha baru terbagi dalam 4 kelompok yaitu berupa jasa dan produk :

1. Produk Budidaya kroto

2. Produk kuliner masakan/katering dan pembuatan kue, produk olahan ayam dan ikan berupa naget, bakso.

3. Jenis produk merchandise (barang dagangan yang berbentuk sablon, dengan bahan dasar seperti muk, tysert, jaket, sovenir dan masih banyak lainnya.

4. Make up artis yang dapat dikembangkan menjadi jasa rias pengantin.

Kegiatan ini dilakukan dalam 3 tahun. Luaranyang didapatkan dari kegiatan ini adalah :

1. Setiap tahunnya menghasilkan wirausaha baru, mandiri, minimal 5 orang (WUB) yang mandiri, setelah mengikuti pelatihan, workshop/seminar, magang dan pameran.

2. Pengembangan produk wirausaha yang inovatif, dimana telah mulai dirintis oleh mahasiswa, dari hasil inovasi produk lama menjadi produk yang baru hasil inovatif seluruh kegiatan ini maksimal anggaran 150 juta, dan dana dari IBI Kosgoro 1957 sebesar 20 juta setiap tahunnya.

Program Pengembangan Kewirausahaan (PPK), ini setiap tahunnya akan membina 20 tenan calon wirausaha setiap tahunnya minimal berhasil minimal 5 tenan sehingga setiap tahunnya dilakukan seleksi lagi sebagai pengganti 5 tenan baru. Seluruhnya adalah $80 \%$ mahasiswa dan $20 \%$ alumni IBI Kosgoro 1957 yang telah merintis usaha namun masih banyak perlu bimbingan. Jumlah entrepreneur di Indonesia masih tertinggal ketimbang negara-negara lain. Berdasarkan Global Entrepreneurship Index (GEI), Indonesia ada di urutan ke 97 dari 136 negara. Berada di bawah Thailand, Malaysia, dan Vietnam.

\section{Tujuan Penelitian}

Tujuan penelitian ini untuk mengetahui Pengembangan Kewirausahaan dengan Pengembangan Usaha Baru.

\section{KAJIAN PUSTAKA}

\section{Kewirausahaan}

Menurut sebuah survei yang dilakukan Peggy Lambing (2000) seperti yang dikutip Suryana (2003: 70), sekitar $43 \%$ responden (wirausahawan) mendapatkan ide bisnis dari pengalaman ketika mereka bekerja di perusahaan atau tempat-tempat profesional lainnya. Dari pengalaman tersebut, mereka mengetahui cara-cara mengoperasikan perusahaan. Sebanyak $15 \%$ responden menyatakan telah mencoba dan merasa mampu mengerjakannya dengan baik. Dari para wirausahawan yang disurvai, $11 \%$ di antaranya memulai usaha untuk memenuhi peluang pasar, sementara 46\% lainnya karena hobi. Sebaliknya calon wirausahawan B berkesimpulan sebaliknya bahwa masyarakat akan mengubah perilakunya kalau ada upaya meng-edukasi masyarakat tersebut untuk bersepatu. Ide-ide bisnis yang dikembangkan oleh seorang wirausahawan pada umumnya merupakan ide-ide praktis yang diyakini memiliki kepastian untuk berhasil. Keberhasilan ini sering berawal dari usaha berskala kecil. 
Oleh karena itu banyak penulis buku kewirausahaan menyarankan, mulailah berbisnis dalam skala kecil (Suharno, 2007 ; Frinzes, 2011 : 223, Saerang et al (2018) \& Tulung et al (2018)).

Analogi seorang yang memulai kewirausahaan ialah seperti seorang belajar naik sepeda, pertama kali duduk di atas sadel sepeda akan merasa gamang dan takut, ragu-ragu untuk memulai mengayuh, takut jatuh atau nabrak namun ketika peadal sepeda muali dikayu dan si anak dapat menguasai rasa takutnya, ternyuata naik sepeda itu mudah semudah berjalan kaki.

Menurut Suryana (2006 : 100) ada 3 (tiga) cara yang dapat dilakukan untuk memulai usaha baru, yaitu :

1. Merintis usaha baru, yaitu membentuk dan mendirikan usaha baru dengan menggunakan modal, ide, organisasi dan manajemen yang dapat dirancang sendiri.

2. Membeli perusahaan orang lain (buying), yaitu dengan membeli perusahaan yang telah didirikan atau dirintis dan diorganisir oleh orang lain dengan nama dan organisasi yang sudah ada.

3. Kerja sama manajemen (franchising), yaitu kerja sama antara wirausaha dengan preusan besar dalam mengadakan persetujuan jual - beli hak monopoli untuk menyelenggarakan usaha (waralaba).

Menjadi seorang entrepreneur sering dipandang sebagai pilihan karir yang menantang, dimana seseorang menghadapi kehidupan sehari - hari dalam situasi kerja yang penuh dengan rintangan kerja, kegagalan, ketidakpastian, dan frustasi yang dihubungkan dengan proses pembentukan usaha yang dilakukan. Gilad dan Levine (Gilad dan Levine dalam Widhari dan Suarta, 2012: 55) mengemukakan dua teori berkanaan tentang dorongan untuk berwirausaha,"push" theory dan "pull” theory.

Menurut Cantillon, wirausaha adalah seseorang yang mampu memindahkan atau mengkonversikan sumbersumber daya ekonomis dari tingkat produktivitas rendah ketingkat produktivitas yang lebih tinggi. Pendapat lain dari Suryana mendefinisikan wirausaha adalah seseorang yang memiliki karakteristik percaya diri, Menurut Schumpeter, wirausahawan adalah seorang inovator yang mengimplementasikan perubahan-perubahan di dalam pasar melalui kombinasikombinasi baru. Kombinasi tersebut bisa dalam bentuk memperkenalkan produk baru atau dengan kualitas baru, memperkenalkan metode atau cara produksi baru, membuka pasar yang baru, memperoleh sumber pasokan baru dari bahan atau komponen baru pada suatu industri. Schumpeter mengkaitkan wirausaha dengan konsep inovasi yang diterapkan dalam konteks bisnis serta mengkaitkannya dengan kombinasi sumber daya.

Menurut Suryana (2013) jiwa kewirausahaan adalah orang yang memiliki cirriciri sebagai berikut: 1. Penuh percaya diri, yaitu penuh keyakinan, optimis, berkomitmen, disiplin dan bertanggungjawab. 2. Memiliki inisiatif, yaitu penuh energI, cekatan dalam bertindak dan aktif. 3. Memiliki motif berprestasi terdiri atas orientasi pada hasil dan wawasan kedepan. 4. Memiliki jiwa kepemimpinan adalah berani tampil beda, dapat dipercaya dan tangguh dalam bertindak. 5. Berani mengambil risiko dengan penuh pertimbangan.

\section{Pengembangan Usaha Baru}

Chandler (dalam Anoraga. 2004 : 339) strategi adalah sasaran dan tujuan jangka panjang sebuah perusahaan , dan arah tindakan serta alokasi sumber daya yang di perlukan untuk mencapai sasaran dan tujuan itu. Strategi adalah kekuatan- kekuatan sumber daya, kapabilitas dan kompetensi inti internal untuk mencapai tujuan perusahaan dalam lingkungan persaingan. Berkaitan dengan memenangkan medan tempur persaingan dan mendapatkan kepemimpinan global, tujuan strategi secara tidak langsung berarti bentang sumber daya, kapabilitas, dan kompetisi inti organisasi. Sehubungan dengan pengembangan usaha, hal ini tergantung pada kemampuan pengusaha dan pengelolanya dalam usahanya setiap hari. Hal ini seperti apa yang di kemukakan oleh Scumpeter (dalam Jhingan, 1993 : 3) bahwa pengembangan adalah perubahan spontan dan terputus-putus senintiasa mengubah dan mengganti situasi keseimbangan untuk waktu sebelumnya. dan dikemukakan oleh Kellog (dalam Moekijat, 2001 : 20) bahwa pengembangan sebagai suatu perubahan dalam diri orang yang memungkinkan yang bersangkutan bekerja efektif.

Menurut Hafsah (2000 : 198) pengembangan adalah upaya yang dilakukan oleh pemerintah, dunia usaha, dan masyarakat melalui pemberian bimbingan dan bantuan perkuatan untuk menumbuhkan dan meningkatkan kemampuan usaha usaha kecil agar menjadi usaha yang tangguh dan mandiri. Sedangkan menurut Mangkuprawira (2004 : 135) menyatakan bahwa pengembangan merupakan upaya meningkatkan pengetahuan yang mungkin 10 digunakan segera atau sering untuk kepentingan di masa depan. Selanjutnya Yoder (dalam Moekijat, 2001 : 20) menjelaskan bahwa pengembangan adalah setiap usaha memperbaiki pelaksanaan pekerjaan yang sekarang maupun yang akan datang, dengan memberikan informasi mempengaruhi sikap-sikap atau menambah kecakapan. Disisi lain Bone (dalam Jhingan, 1993:4) mengatakan bahwa pengembangan adalah memerlukan dan melibatkan semacam pengarahan, pengaturan, dan pedoman dalam rangka menciptakan kekuatan-kekuatan bagi perluasabn 
pemeliharaan. Sedangakan dalam kamus besar bahasa indonesia (1994:655) menyatakan bahwa pengembangan adalah cara atau hasil kerja mengembangkan sesuatu (pekerjaan, usaha, kepribadian dan lain sebagainya).

Dalam memenuhi kebutuhan manusia, maka usaha dapat menimbulkan adanya dunia usaha yang menciptakan barang dan jasa. Menurut Hornby (Enskplodiya 2000 : 402) effort is a particular activity that a group of people organize in order to achive something. Yaitu, usaha adalah aktivitas khusus yang diorganisir oleh sekelompok orang untuk mencapai tujuan atau sesuatu. Menurut Saparudin (2003 : 1) menyatakan bahwa usaha adalah suatu kegiatan yang dilakukan oleh perorangan atau kelompok untuk mendapatkan penghasilan dengan tujuan memperoleh keuntungan, sedangakan usaha menurut kamus umum bahasa indonesia (1994 : 1661) adalah kegiatan dengan menggunakan tenaga pikiran atau badan untuk menyatakan suatu maksud.

\section{Penelitian Terdahulu}

Jusoh et al (2011), Penelitian tersebut menunjukkan bahwa tingkat keterampilan kewirausahaan pengusaha yang disurvei cukup terampil, dan mereka merasa bahwa mereka membutuhkan pelatihan keterampilan kewirausahaan di berbagai bidang seperti untuk meningkatkan kreativitas dan inovasi, keterampilan untuk membuat akun bisnis, menciptakan promosi iklan dan keterampilan, keterampilan menetapkan harga yang tepat dan keterampilan menjual. Studi ini menunjukkan bahwa pengusaha bereaksi terhadap perubahan dalam lingkungan bisnis saat ini yang membutuhkan pengusaha kreatif dan inovatif untuk menyediakan barang dan jasa yang lebih kompetitif dan layak (Rosnani dan Soaib Asimiran, 2007), selain itu melalui pelatihan dan pendidikan kewirausahaan yang akan diberikan kepada pengusaha berdasarkan keterampilan yang dibutuhkan oleh pengusaha dalam penelitian ini dapat menyumbangkan pengetahuan, keterampilan dan pengalaman untuk bisnis (Dana, 2001).

Jarkasih (2008), Penelitian ini peneliti ingin mengetahui pengaruh kemampuan manajerial pengusaha sepatu untuk industri kecil di daerah cibaduyut, dimana berdasarkan hasil analisis yang telah dilakukan tingkat kemampuan manajerial berada pada kategori sedang, beberapa faktor yang melatarbelakangi inkonsistensi manajeman perusahaan. Faktor-faktor tersebut diantranya ialah keengganan untuk menerapkan keterbatasan modal, keterbatasan sumber daya manusia, dan alasan yang paling mendasar adalah keterbatasan pengetahuan teori manajemen. Dan selanjutnya ialah hasil analisis menyebutkan dalam penelitian diperoleh data mengenai tingkat keberhasilan usaha pengusaha sepatu mayoritas berada pada posisi keberhasilan usaha yang rendah. Hasil analisis terakhir yang dilakukan secara keseluruhan dapat dibuktikan bahwa kemampuan manajerial pengusaha berpengaruh secara positif dan keberhasilan usaha pengusaha sepatu juga dipengaruhi oleh faktor lain yaitu dari internal perusahaan berupa perilaku kewirausahaan dan faktor eksternal perusahaan seperti kebijakan ekonomi pemerintah.

Waspada (2004), Penelitian tersebut menjelaskan perilaku seseorang dalam menghadapi suatu keadaan tertentu membawa pengaruh pada apa yang dikerjakan, baik berupa hasil maupun orientasi pengembangan dalam usahanya. Hal ini tercermin dalam motivasi yang timbul dalam diri wirausaha tersebut sebagai pendorong untuk terus maju. Hal yang paling mendasari perilaku kewirausahaan dalam mencapai keberhasilan usahanya adalah kebutuhan akan prestasi (need for achievement), karena prestasi adalah titik tolak dari pencapaian sukses. Sukses itu adalah bagian terpenting meraih profit. karena itu kebutuhan erat hubungannya dengan pekerjaan dan mengarahkan tingkah laku pada usaha untuk mencapai prestasi tertentu. Usaha kecil memiliki, peluang untuk mengembangkan perilaku wirausaha dengan baik, sehingga sukses profit yang diharapkan mampu mengembangkan community base industry.

Agustini dan Yudiati (2002), Penelitian tersebut dijelaskan bahwa keterkaitan antara keberhasilan usaha dengan jiwa kewirausahaan dan manajemen usaha menggunakan responden yang memiliki jiwa wirausaha dan mengetahui tentang manajemen usaha yang dijalankan. Hasil psikotes untuk mengungkapkan jiwa kewirausahaan responden diperoleh kesimpulan bahwa atas dasar hasil tes EPPS ternyata sebagian besar responden memiliki potensi yang tinggi pada semua karakteristik atau jiwa kewirausahaan yang harus dimiliki seorang wirausahawan, kecuali untuk karakter autonomy.

\section{Hipotesis Penelitian}


Ide-ide untuk memulai sebuah usaha atau bisnis diawali dengan mengamati lingkungan. Biasanya ide baru muncul sebagai hasil dari proses interaksi seseorang dengan lingkungan. Oleh karena itu pilihan akan lingkungan dan bentuk bisnis harus diamati dengan seksama. Di sini seorang wirausahawan harus jeli dalam menilai dan menangani berbagai permasalahan dan peluang yang muncul di lingkungan tersebut.

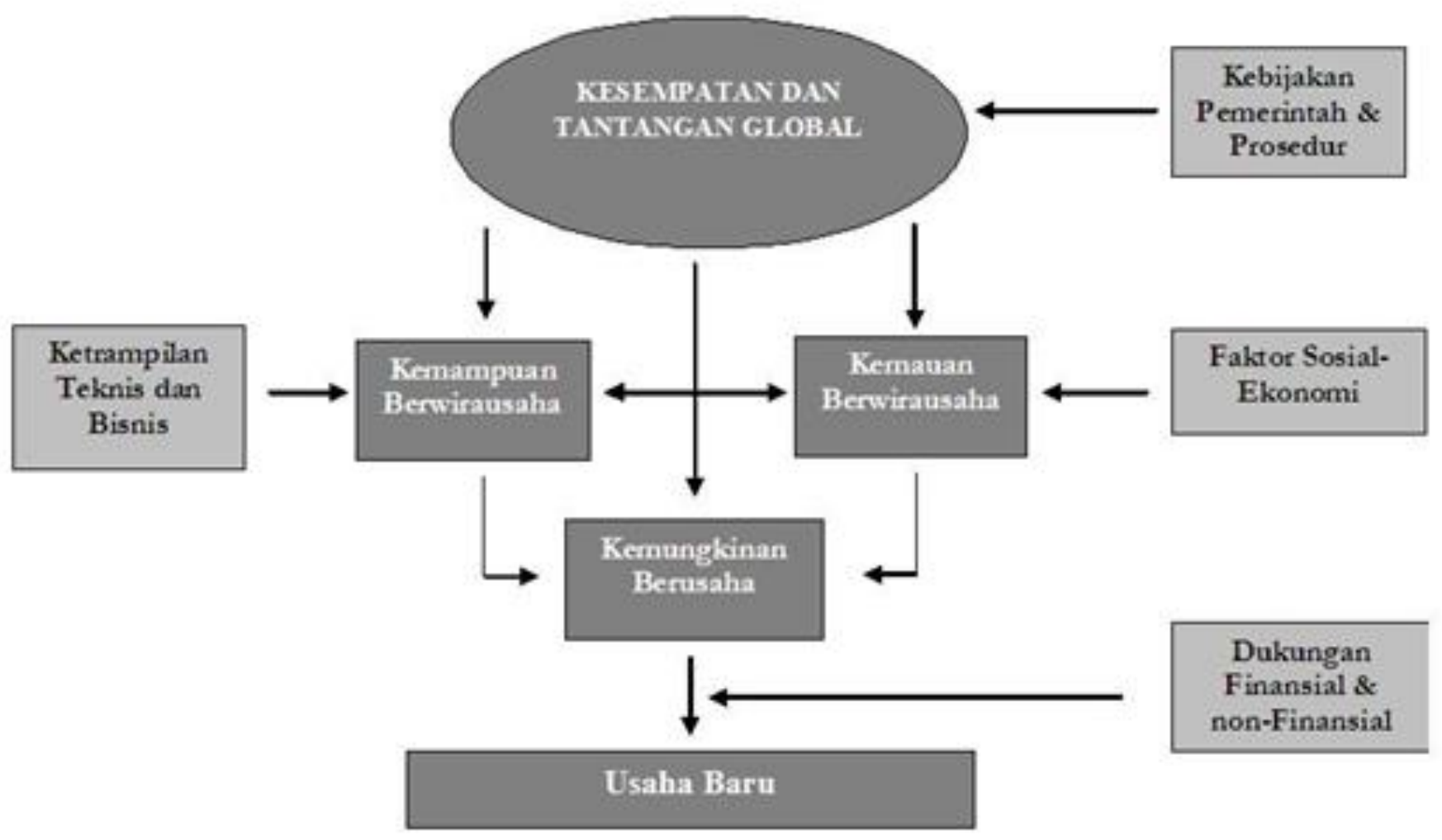

\section{Gambar 1. Hubungan Kewirausahaan dengan Lingkungan}

\section{METODE PENELITIAN}

Analisis data penelitian kualitatif dapat dilakukan melalui tiga alur kegiatan yang terjadi secara bersamaan yaitu: 1) reduksi data (data reduction), 2) penyajian data (data displays dan 3) penarikan kesimpulan/verifikasi (conclusion drawing/veriffication). Dalam penelitian ini peneliti menggunakan analisis deskriptif dengan menerangkan proses berfikir induktif yaitu berangkat dari faktor- faktor khusus, peristiwa-peristiwa yang konkrit kemudian dari faktor-faktor atau peristiwa yang khusus dan konkrit kemudian itu ditarik generalisasi yang bersifat umum (Miles\& Huberman, 2009).

\section{Populasi dan Sampel}

Populasi dan sampel pada penelitian ini adalah Informan para Wirausahaan yang lama berkecimpung dalam dunia bisnis dan informan wirausahawan yang menciptakan produk baru di jaman 4.0.

\section{Metode Analisis}

Metode analisa yang digunakan adalah penelitian kualitatif dengan studi kasus, Fokus penelitian pada Kewirausahaan dengan sub fokus pada penelitian penciptaan baru usaha era 4.0

\section{HASIL PENELITIAN DAN PEMBAHASAN}


Proses seleksi calon tenant dilakukan secara bertahap sebagai berikut: (1) sosialisasi kepada mahasiswa yang berminat di bidang kewirausahaan,(2) melakukan seleksi (recruitment test) terhadap pendaftar program PPK, (3) sejumlah 20 orang mahasiswa yang sudah berhasil lolos dari recruitment test diperbolehkan mengikuti program entrepreneurship capacity building, yaitu (1)diklat kewirausahaan,(2)magang kewirausahaan, (3)Inkubator kewirausahaan. Dari 20 mahasiswa yang digodok dalam program pembentukan kapasitas wirausaha dapat dihasilkan 5-10 mahasiswa wirausaha baru mandiri per tahun yang siap berkompetisi di masyarakat. Pola recruitment peserta program PPK mahasiswa seperti yang di tunjukan pada gambar 2.

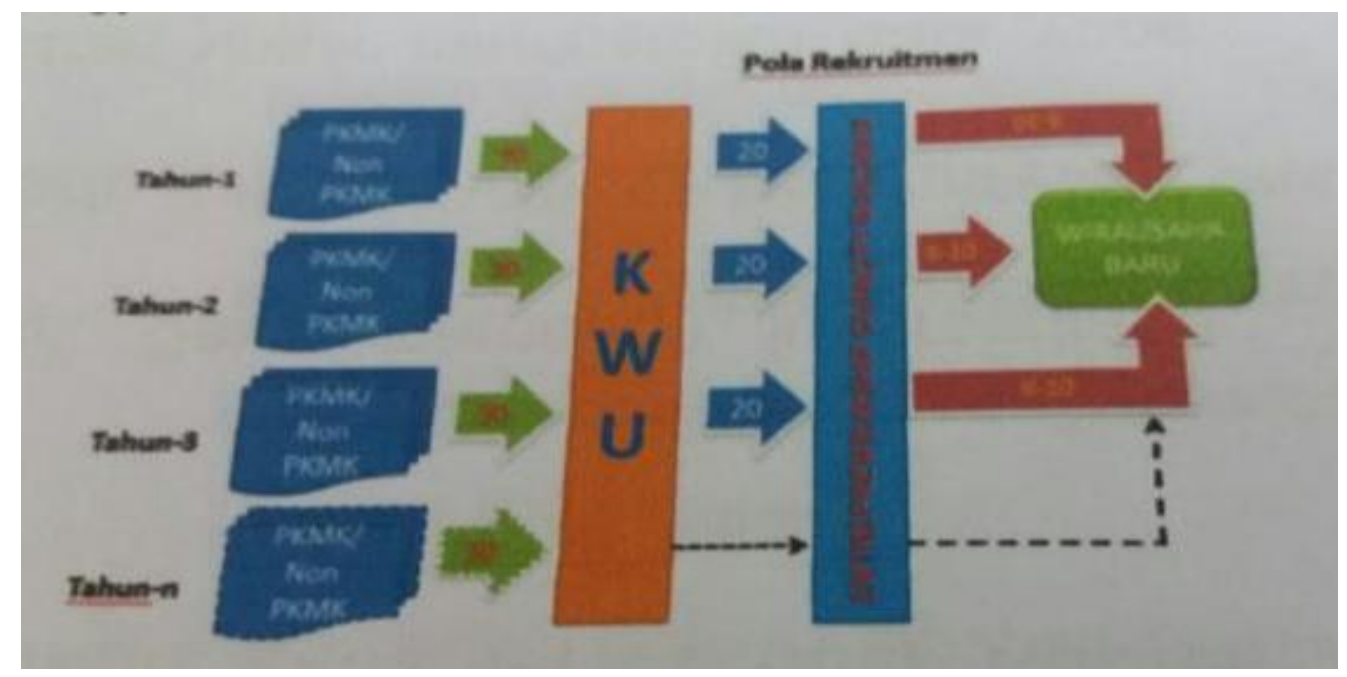

Gambar 2. Pola Recruitment Peserta Program PPK Mahasiswa

Mahasiswa dalam konteks pemberdayaan potensi entrepreneurship mahasiswa. Mahasiswa menggunakan metode PALS (Participatory Action Learning System).Prinsip dasar dari metode PALS adalah pelibatan mahasiswa dalam proses pembelajaran aktif partisipan dalam program kewirausahaan (entrepreneurship) secara alamiah dengan segala pendekatan sehingga membentuk suatu sistem interaksi pembelajaran secara partisipatif, baik secara personal maupun komunal. Metode PALS menitikberatkan pada transformasi kegiatan-kegiatan yang telah ada untuk diusahakan dibawa pada perubahan-perubahan ke arah perbaikan kondisi entrepreneurship mahasiswa melalui (1) fase penyadaran kewirausahaan ( awareness) (2) fase pengkapasitasan (capaciting) dan pendampingan (scaffolding) kewirausahaan (entrepreneurship capacity building), dan (3) fase pelembagaan (institutionalization) usaha baru sebagai wirausaha baru. Metode pendekatan inkubator bisnis mahasiswa dengan metode PALS secara digramatik ditunjukan pada gambar 3 .

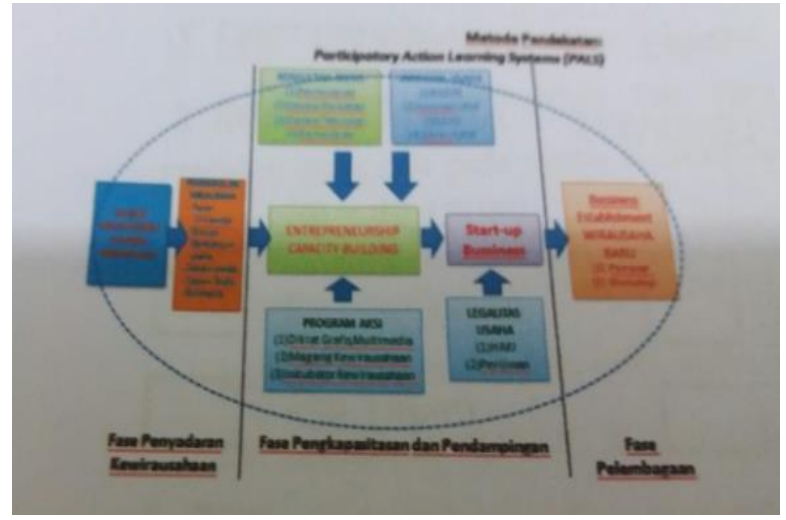

\section{Gambar 3. Metode Participatory Action Learning Systems}

a. Fase Penyadaran Kewirausahaan 
Bertujuan membentuk dan mengembangkan sikap dan perilaku "entrepreneur" yang mampu berkreasi, menciptakan inovasi, dan proaktif dalam menghadapi perkembangan lingkungan. Bentuk teknis pelatihan yang diterapkan adalah classical, studi kasus, diskus, dan simulasi.

1. Pembekalan awal berupa motivasi entrepreneurship dan peran perguruan tinggi dalam pengembangan bisnis mahasiswa meliputi aspek, antara lain : motivasi usaha, permodalan, manajemen, hingga pemasaran produk dan jasa.

2. Pembekalan berkaitan dengan cara memulai, mengembangkan dan mempertahankan usaha dengan kasus UKM di kota Jakarta Selatan.

3. Pembekalan desain, dibahas tentang peran desain produk dan desain grafis dalam menunjang kegiatan usaha sehingga usaha dapat berkembang. Pencerahan juga diberikan pegiat kegiatan usaha.

4. Pembekalan materi multimedia, menjelaskan peluang dan prospek bisnis multimedia dan penggunaaan multimedia untuk mengembangan bisnis.

b. Fase Pengkapasitasan dan Pendampingan merupakan fase yang lebih mengarah pada upaya memperkuat perintisan usaha para peserta (tenant).Tahap ini dimulai dengan mengajak seluruh peserta ke unit-unit usaha kecil dan menengah (UKM) di kota Jakarta yang telah melaksanakan kegiatan usaha lebih dari 10 tahun dan sudah pernah melakukan penjualan hingga manca negara (export), sehingga dalam interaksi antara tenant dengan pengusaha para tenant mendapat cerita tentang bagaimana memulai usaha, mengembangkan dan mempertahankan usaha. Dalam kegiatan ini beberapa tenant melakukan konsultasi usahanya untuk memantabkan tekad membuka dan memulai usaha.

\section{Pembahasan}

Luaran yang dicapai saat ini adalah :

a. Jasa atau produk Wirausaha Baru

(WUB), mahasiswa yang memiliki keunggulan iptek, antara lain:

1. Produk, Merchandise

2. Makanan

Dari 20 mahasiswa yang melakukan kegiatn inkubator bisnis mahasiswa, terdapat 6 orang yang sudah mantab usahannya.Sementara 14 mahasiswa masih melakukan rintisan usaha

b. Pembentukan jaringan usaha tenant dengan stakeholders

1. Himpuan Pengusaha Kosgoro

2. Himpuan Pengusaha muda Jakarta Selatan

3. Ikatan Kamar Dagang dan Industri Indonesia

\section{PENUTUP}

\section{Kesimpulan}

Inkubator Bisnis Mahasiswa merupakan program yang tepat untuk menumbuhkembangkan jiwa wirausaha dan mengentaskan wirausaha baru dari kalangan mahasiswa dan perguruan tinggi.Peserta Inkubator Mahasiswa telah melakukan proses pembinaan meliputi tiga fase, yaitu fase penyadaran kewirausahaan, fase pengkapasitasan serta fase pendampingan dan pelembagaan.Peserta inkubator mahasiswa mendapatkan pengalaman praktis yang tidak diperoleh di bangku kuliah sehingga permasalahan-permasalahan lapangan telah mereka ketahui dari interkasi dengan para pelaku usaha dan para nara sumber pada sesi pembekalan wirausaha.

\section{Saran}

Program pengembangan Wirausaha Mahasiswa merupakan program pembinaan usaha mahasiswa yang lengkap dan terstruktur sehingga diperlukan pemahaman yang sama antara pelaksanaan program dengan para Ketua Program Bidang Studi, Dekan, Badan Kemahasiswaan dalam mencapai kemandirian mahasiswa dan alumni dalam pengembangan usaha. Perlu kerjasama anatar perguruan tinggi yang mempunya program pengembangan kewirausahaan sehingga dapat dilakukan kerjasama dalam bentuk kegiatan bersama, misalnya pameran produk, konsultasi bisnis, kontak bisnis, dll. Perlu kerjasama yang lebih intebsif dengan stakeholders bidang usaha,antara lain : Dewan Kerajinan Nasional Daerah (Dekranasda) serta dinas terkait seperti ,Dinas Perindustrian dan Perdangangan. 


\section{DAFTAR PUSTAKA}

Adam, K \& Jessica, K. 2000. Ensiklopedi Ilmu-Ilmu Sosial. Edisi I. Jakarta.

Agustini, D.H \& E.A. Yudiati. (2002). Keterkaitan Keberhasilan Usaha dengan Jiwa Kewirausahaan dan Manajemen Usaha Pada Pedagang Eceran Berskala Kecil di Semarang. Jurnal Ekonomi dan Bisnis (Dian Ekonomi) Volume VIII No. 3 Desember 2002, Hal 357-374

Alas, R., Übius, U., Lorents, P., \& Matsak, E. (2017). Corporate Social Responsibility In European And Asian Countries. Jurnal Manajemen Bisnis Dan Inovasi (JMBI) UNSRAT Vol. 4 No. 1

Anoraga, P. (2004). Manajemen Bisnis. Cetakan Ketiga. Penerbit Rineka Cipta. Jakarta.

Cantillon R. (1755). Essai Sur la nature de la Commerce en General (Edited by H.Higgins- 1931), Mcmillan, London.

Fauzi, A. (2018). Peran Analisis Kredit Terhadap NPL pada PT. X. Jurnal Manajemen Bisnis Dan Inovasi (JMBI) UNSRAT Vol. 5 No. 2

Hafsah, M. J. (2000). Kemitraan Usaha: Konsepsi dan Strategi, Jakarta: PT. Pustaka Sinar Harapan.

Jusoh, R., Ziyae, B., Asmirian, S., Abd. Kadir, S. (2011). Entrepreneur Training Needs Analysis Implications on The Entrepreneurial Skill Needed for Successful Entrepreneurs, International Business \& Economic Research Journal - January 2011 Vol 10, Number 1

Saerang, D. P. E., Tulung, J. E., \& Ogi, I. W. J. (2018). The influence of executives' characteristics on bank performance: The case of emerging market. Journal of Governance \& Regulation, 7(4), 13-18.

Suharno. (2010). Dasar-Dasar Kebijakan Publik. Yogyakarta: UNY Press.

Suryana. (2008). Kewirausahaan (Pedoaman Praktik: Kiat dan Proses Menuju Sukses), Salemba Empat, Jakarta

Suryana. (2013). Kewirausahaan Kiat dan Proses Menuju Sukses. Jakarta: SALEMBA EMPAT

Tulung, J. E., Saerang, I. S., \& Pandia, S. (2018). The influence of corporate governance on the intellectual capital disclosure: a study on Indonesian private banks. Banks and Bank Systems, 13(4), 61-72.

Widhari, C. I., \& I Ketut Suarta, S. (2012). Analisis Faktor-faktor yangMemotivasi Mahasiswa Berkeinginan Menjadi Wirausaha. Jurnal Bisnis dan Kewirausahaan Vol 8 No 1 Maret 2012. Hal 54-63

Zarkasyi, M. W. (2008). Good Corporate Governance Pada Badan Usaha Manufaktur, Perbankan, dan Jasa Keuangan Lainnya. Bandung: Alfabeta. 